\title{
Electrolyzed water as a green cleaner: chemical and physical characterization at different electrolysing parameters
}

\author{
${ }^{1}$ Khalid, N.I., ${ }^{1}$ Sulaiman, S., ${ }^{1 *}$ Ab Aziz, N., ${ }^{1}$ Taip, F.S., ${ }^{2}$ Sobri, S. and \\ ${ }^{3}$ Nor-Khaizura, M.A.R. \\ ${ }^{1}$ Department of Process and Food Engineering, Faculty of Engineering, Universiti Putra Malaysia, 43400, \\ UPM Serdang, Selangor, Malaysia. \\ ${ }^{2}$ Department of Chemical and Environmental Engineering, Faculty of Engineering, Universiti Putra \\ Malaysia, 43400, UPM Serdang, Selangor, Malaysia. \\ ${ }^{3}$ Department of Food Science, Faculty of Food Science and Technology, Universiti Putra Malaysia, 43400, \\ UPM Serdang, Selangor, Malaysia.
}

\begin{abstract}
Article history:
Received: 25 May 2018

July 2018

Accepted: 25 July 2018

Available Online: 6

November 2018

\section{Keywords:}

Sustainable cleaning,

Cleaning medium,

Sanitation,

Electrolysis,

Food industry
\end{abstract}

Received in revised form: 25

DOI:

http://doi.org/10.26656/fr.2017.2(6).107

\begin{abstract}
The aims of this study were to develop electrolysed technique and evaluate the characteristics and performance of electrolysed water that will be applied as a cleaning medium in the food industry. Acidic electrolyzed water (AcEW) and neutral electrolyzed water (NEW) have been reported to have a strong bactericidal effect on various types of foodborne pathogens for many types of food products and food equipment surfaces. While alkaline electrolyzed water (AlEW) is a potential cleaning medium for alkaline wash. The shelf life of electrolyzed water generated from the lab-scale electrolyzing unit was investigated to obtain the best quality electrolyzed water for a long duration. The electrolyzed water was stored in closed dark-brown glass bottles at room temperature. Effect of electrolyzing parameters (electrode type, $\mathrm{NaCl}$ concentration, electrical voltage and electrolysis time) on chemical and physical properties ( $\mathrm{pH}$, oxidation-reduction potential (ORP), total chlorine, free chlorine, dissolved oxygen) of electrolyzed water (alkaline, acidic, and neutral electrolyzed water) were studied. The chemical and physical properties of electrolyzed water were measured after $24 \mathrm{hrs}$. Results showed that as time increased, the chemical and physical properties of electrolyzed decreased and eventually reduced the electrolyzed water quality. Freshly prepared electrolyzed water is suggested for cleaning application in food industry. The usage of electrolyzed water is expected to help the food industry in achieving a hygienic environment in their factory and at the same time minimizing the cleaning cost.
\end{abstract}

\section{Introduction}

Daily cleaning procedure in the food industry is compulsory and application of commercial cleaning chemicals are common and costly. Cost of cleaning includes the cost of water, energy, chemical, wastewater treatment, and downtime. Cleaning chemical may affect the total cleaning cost greatly (Khalid et al., 2016). Studies performed by Khalid et al. (2016) has shown that cleaning performed with a high concentration of $2.0 \mathrm{wt}$ $\%$ of $\mathrm{NaOH}$ need almost extra $\$ 1400 / \mathrm{m}^{2}$ of fouling deposit area, compared to cleaning performed without $\mathrm{NaOH}$. When cleaning was performed without $\mathrm{NaOH}$, the fouled stainless steel cannot reach $100 \%$ physically clean condition. Since awareness of the environment is well received by food manufacturers and researchers, they are looking for green cleaners which have the same ability as the commercial cleaning chemicals and at the same time give less impact to the environment.

Electrolyzed water (EW) is seen as a good opportunity to reduce the chemical consumption cost (Dev et al., 2014; Wang et al., 2016). The EW is generated by using the EW generator. Thus, food manufacturer only needs to buy the generator once and they can use the EW immediately. They do not have to waste time to order the cleaning chemical and do not need storage space for cleaning chemical as the electrolyzed water can be generated onsite. Thus, it can save the cost for chemical and also storage space. Moreover, considering this process only use tap water and $\mathrm{NaCl}$, it can also be considered to be environmental 
friendly (Wang et al., 2016).

Acidic electrolyzed water (AcEW) and neutral electrolyzed water (NEW) is relatively a novel antimicrobial agent that is highly effective against foodborne microbe such as Escherichia coli (Venkitanarayanan et al., 1999; Kim et al., 2000; Park et al., 2004), Salmonella (Venkitanarayanan et al., 1999; Fabrizio and Cutter, 2004) and Listeria monocytogenes (Venkitanarayanan et al., 1999; Park et al., 2004). While AlEW can be used as an alternative to alkaline wash for cleaning. AlEW can remove food residue, dirt and grease from food-contact surfaces such as stainless steel (Walker et al., 2005; Dev et al., 2014; Wang et al., 2016), cutting boards and kitchen utensils (Hsu, 2005), PVC milk hose, rubber liners, rubber gaskets, and polysulfone plastic (Walker et al., 2005). However, the chemical and physical properties of AlEW and its effectiveness as an alternative alkaline wash has not well -defined in the literature.

Researchers suggested that $\mathrm{pH}$ (McPerson, 1993), chlorine compound (Park et al., 2004; Liu et al., 2006), ORP (Kim et al., 2000; Liao et al., 2007) or combinations of these factors (Huang et al., 2008) are responsible in the antimicrobial activity by AcEW. Bacteria usually grow at a $\mathrm{pH}$ range of 4 to 9 (Huang et al., 2008). Moreover, aerobic bacteria and anaerobic bacteria can optimally grow at ORP range of +200 to $+800 \mathrm{mV}$ and -700 to $+200 \mathrm{mV}$, respectively. Due to the change in the electron flow in the cell, AcEW with higher ORP $(>1000 \mathrm{mV})$ causes the modification of metabolic fluxes and ATP production of the bacteria. The low $\mathrm{pH}(2.3-2.7)$ of AcEW may sensitize the outer membrane of bacterial cells to allow Hypochlorous acid (HOCl) to enter into bacterial cells (McPherson, 1993). $\mathrm{HOCl}$ is the most active of the chlorine compounds. $\mathrm{HOCl}$ kills the microbial cell by inhibiting glucose oxidation by chlorine-oxidizing sulfhydryl groups of certain enzymes that are important in carbohydrate metabolism. Different types of foodborne microbes have different resistance ability against cleaning medium. Thus, it is important to understand the physico-chemical of EW in order to create suitable EW for various types of microbes.

The objective of this work was to investigate the effect of electrolyzing parameters (electrode type, $\mathrm{NaCl}$ concentration, electrical voltage and electrolysis time) on chemical and physical properties $(\mathrm{pH}$, oxidationreduction potential (ORP), chlorine, dissolved oxygen, electrical conductivity) of EW (alkaline, acidic, and neutral). The shelf life of EW was also studied in this work. The optimal operating parameters are expected to help the food industry in designing a green cleaner and sanitiser which can help in achieving a hygienic environment in their factory and at the same time minimizing the cleaning cost.

\section{Materials and methods}

\subsection{Preparation of electrolyzed water}

Electrolyzed water was generated using a laboratoryscale batch electrolyzing unit. This unit (Figure 1) was designed and constructed at the Department of Process and Food Engineering, Faculty of Engineering, Universiti Putra Malaysia, Malaysia. There were two chambers (cathode and anode chamber) in this unit, which were separated by a membrane that allowed ion exchange. AcEW and AlEW were collected at anode and cathode chambers respectively. While NEW was generated using one chamber (membrane was dissembled during electrolysis process). Electrolysis experiments were carried out using different electrolysing parameters (electrode type (titanium, silver, stainless steel), $\mathrm{NaCl}(0.1-1.0 \% \mathrm{NaCl})$ concentration, electrical voltage $(9-24 \mathrm{~V})$ and electrolysis time (10-30 mins)). In this work, titanium was used as the anode and different electrode types (stainless steel and silver) were used as the cathode.

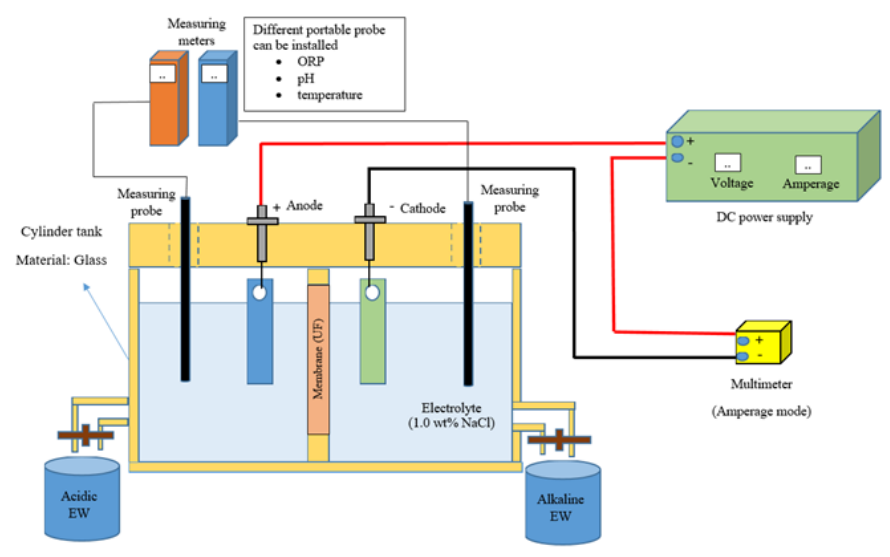

Figure 1. Schematic diagram of the lab-scale electrolyzing unit

\subsection{Analytical measurement of electrolyzed water}

$\mathrm{pH}$ was measured using $\mathrm{pH} / \mathrm{mV} / \mathrm{ISE}$ meter equipped with $\mathrm{pH}$ electrode (Fisher Scientific, USA). Oxidation-reduction potential (ORP) was measured using $\mathrm{pH} / \mathrm{mV} / \mathrm{ISE}$ meter equipped with redox electrode (Boeco, Germany). ORP was measured in millivolts and it is a measurement that indicates the tendency of a chemical substance to oxidize or reduce another chemical substance. Dissolved oxygen concentration of electrolyzed water was measured using an oxygen meter (Hanna Instruments, USA). Dissolved oxygen refers to the level of free, non-compound oxygen present in water or other liquids. Free chlorine and total chlorine were measured using Photometer (Macherey-Nagel, Germany).

(C) 2018 The Authors. Published by Rynnye Lyan Resources 


\subsection{Shelf life or storage of electrolyzed water}

The effect of storage was studied based on the changes of the physical and chemical properties of electrolyzed water. $20 \mathrm{~mL} \mathrm{EW}$ (AcEW, AlEW, and NEW) was stored for 1 day ( $24 \mathrm{hrs}$ ) in a dark brown tightly screw close bottle. All of the bottles were stored at room temperature $\left(25-30^{\circ} \mathrm{C}\right)$. An evaluation of the quality of the electrolyzed water was carried out after the electrolysis process and after $24 \mathrm{hrs}$ of storage.

\subsection{Electrolysis efficiency}

Current efficiency is the ratio of the actual mass of a substance liberated from an electrolyte by the passage of current to the theoretical mass liberated according to Faraday's law. In this work, current density, current efficiency, and electrical efficiency were determined using Equation 1 to 3 (Hsu, Hsia, Hsu, 2015a, 2015b; Hsu and Hsu, 2016; Hsu, Lu, Hsu, 2017). Theoretical production of total chlorine was calculated using Equation 4 to 6.

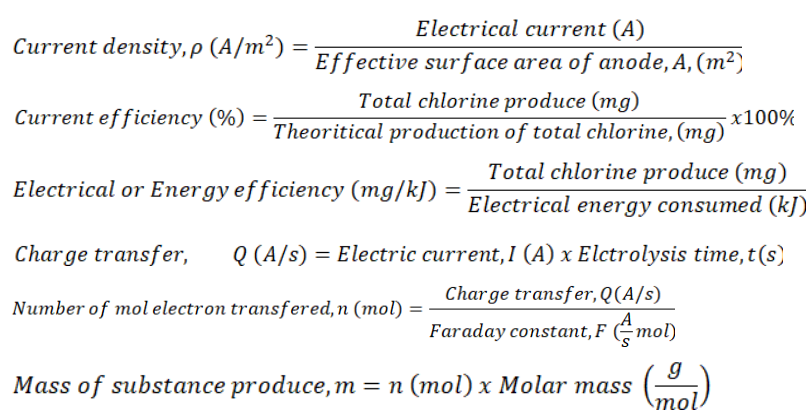

\subsection{Statistical analysis}

A three-level three-factor Box-Behnken design (BBD) generated using Design Expert software (Stat Ease Corp, USA) was performed to study the effect voltage, electrolyzing time and $\mathrm{NaCl}$ concentration on acidic and alkaline electrolyzed water. In this study, $\mathrm{pH}$, ORP, free chlorine and total chlorine of electrolyzed water were selected as the response. Correlations were considered statistically significant at a $95 \%$ confidence interval $(p<0.05)$. However, details statistical analyses of the data was not reported in this paper.

\section{Results and Discussion}

3.1 Effect of different electrode types on the physicochemical properties of electroyzed water

In this work, titanium was used as the anode and two different types of electrodes (silver, stainless steel) were used as the cathode. In selecting a suitable material as an electrode, several factors were considered. The electrode should preferably be made from a material with 1) high conductivity, 2) resistance to corrosion 3) resistance to erosion and 4) able to catalyse the electrode reactions. Moreover, the electrode should be relatively inexpensive for industrial use, especially for Small and Medium Enterprise (SMEs) food factories. Platinum is an excellent material for electrode but it is expensive. Selection of electrodes types can affect the production of free chlorine in EW. The effectiveness of the material as an electrode depends on the electrical conductivity of the material, $\sigma$ (Hsu, Hsia, Hsu, 2015b) and exchange current density, $i_{0}$ of material (Natarajan, 2018).

Effect of different electrodes (platinum and titanium) on chlorine production was studied by Hsu, Hsia, Hsu, (2015b). Results from Hsu, Hsia, Hsu, (2015b) shows that the pair of titanium as cathode and anode produced a minimum amount of chlorine $\left(3 \mathrm{mg} \mathrm{Cl}_{2} / \mathrm{L}\right)$. $\mathrm{Hsu}, \mathrm{Lu}, \mathrm{Hsu}$, (2017) stated that this might happen because titanium is not a good electrical conductor. However, when $\mathrm{Hsu}, \mathrm{Lu}$, Hsu (2017) replaced the anode with platinum, the chlorine produced increased significantly to $2582 \mathrm{mg}$ $\mathrm{Cl}_{2} / \mathrm{L}(\mathrm{p}<0.05)$. Then, using platinum as both anode and cathode furtherly increased the production of chlorine (3325 $\mathrm{mg} \mathrm{Cl} / \mathrm{L}$ ). However, it is not significantly different when platinum was used as anode and titanium was used as the cathode $(2582 \mathrm{mg} \mathrm{Cl} / 2$ ). Hsu, $\mathrm{Lu}, \mathrm{Hsu}$, (2017) also stated that even though platinum is an excellent material for electrode, but it is still expensive.

Table 1 shows physico-chemical properties of electrolyzed water generated using the laboratory-scale electrolyzing unit at 30 mins electrolysis time at different electrolyzing parameters. In contrast to Hsu, Hsia, Hsu (2015b) claim, at $0.5 \% \mathrm{NaCl}$, stainless steel with lower electrical conductivity $\left(1.45 \times 10^{6} \mathrm{~S} / \mathrm{m}\right)$ can produce higher total chlorine $(0.50 \mathrm{mg} / \mathrm{L})$ as compared to silver $\left(\sigma\right.$ of $6.30 \times 10^{7} \mathrm{~S} / \mathrm{m}$ that produce $0.17 \mathrm{mg} / \mathrm{L}$ total chlorine) (Comparison Run 1 and Run 4). However, the chlorine generated was far behind the chlorine produced using commercialized electrolyzing unit (data not presented). This might be due to the low current efficiency due to the usage of stainless steel rod and hook to connect the electrode plate and power supply. In the future, improvements should be made to increase current efficiency.

Platinum has the highest current density, $i_{0}$ as compared to other materials such as silver, aluminium, iron, mercury, palladium and many more which means it is easier to reduce hydrogen ions from the acidic electrolyte on a platinum electrode $\left(\mathrm{i}_{0}=10^{-2}\right)$ unlike on mercury electrode $\left(i_{0}=10^{-13}\right)$ (Natarajan, 2018). Mercury possesses a high hydrogen-overvoltage. Electrodes with higher $\mathrm{i}_{0}$ can produce higher chlorine content by Jeong et al. (2009) mentioned that an electrode with higher current densities can produce higher chlorine content. Jeong et al. (2009) used 5 types of material (Ti/IrO2, Ti/ $\mathrm{RuO} 2, \mathrm{Ti} / \mathrm{Pt}-\mathrm{IrO} 2, \mathrm{BDD}, \mathrm{Pt})$ as anode in the electrolysis 


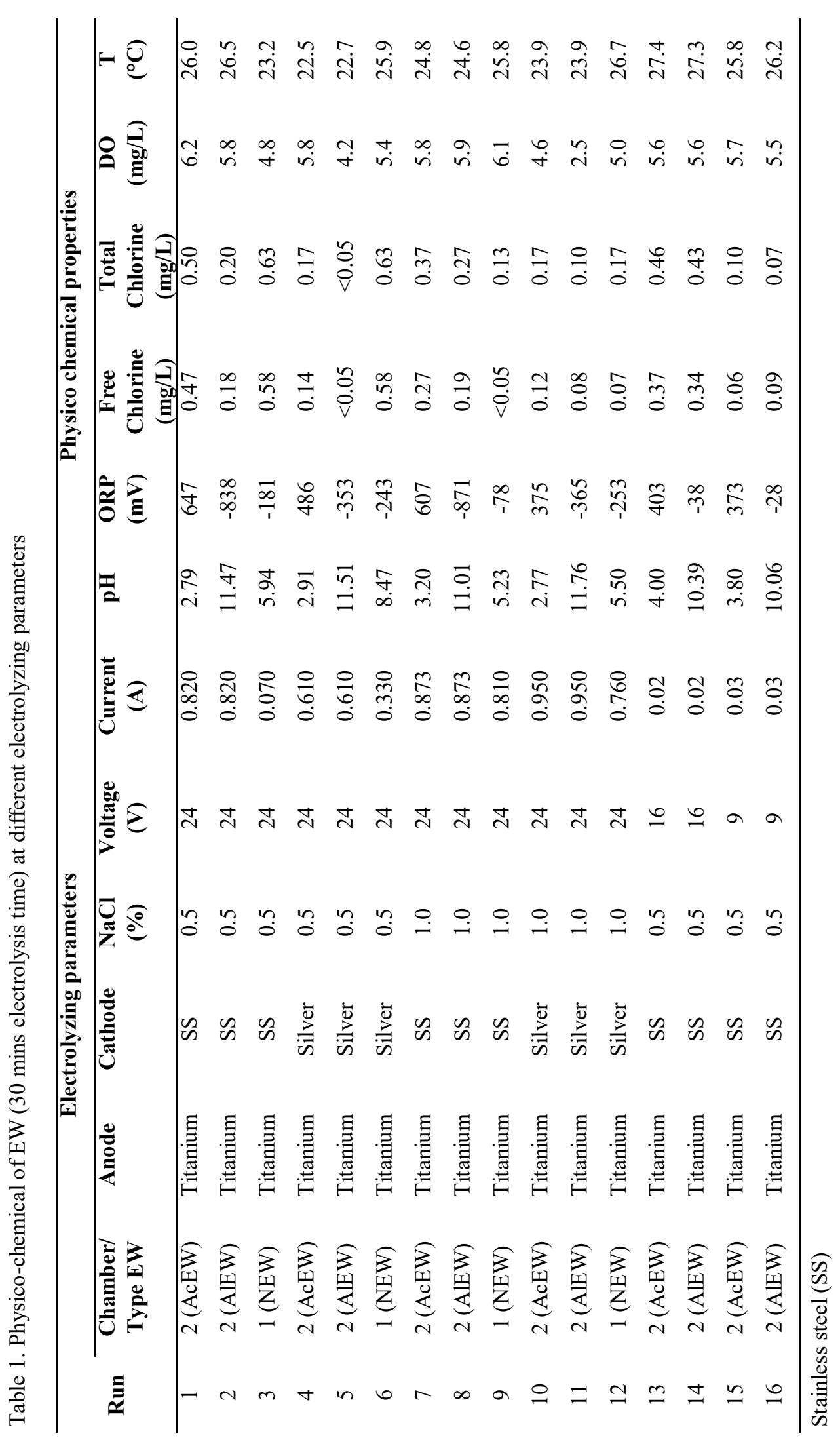


Table 2. Current efficiency for stainless steel cathode using $1.0 \% \mathrm{NaCl}$.

\begin{tabular}{|c|c|c|c|c|c|}
\hline Voltage (V) & Current (A) & $\begin{array}{l}\text { Total Chlorine } \\
(\mathrm{mg} / \mathrm{L})\end{array}$ & $\begin{array}{l}\text { Theoretical Total } \\
\text { Chlorine }(\mathrm{mg} / \mathrm{L})\end{array}$ & $\begin{array}{c}\text { Current } \\
\text { efficiency }(\%)\end{array}$ & $\begin{array}{l}\text { Current density, } \boldsymbol{\rho} \\
\left(\mathrm{A} / \mathrm{m}^{2}\right)\end{array}$ \\
\hline \multicolumn{6}{|c|}{$10 \mathrm{~min}$} \\
\hline 9 & 0.01 & 0.23 & 0.28 & 83.46 & 0.63 \\
\hline 16 & 0.02 & 0.24 & 1.10 & 21.77 & 2.50 \\
\hline 24 & 0.31 & 0.25 & 17.09 & 1.46 & 38.75 \\
\hline \multicolumn{6}{|c|}{$20 \mathrm{~min}$} \\
\hline 9 & 0.01 & 0.36 & 0.55 & 65.32 & 0.63 \\
\hline 16 & 0.01 & 0.41 & 1.54 & 26.57 & 1.75 \\
\hline 24 & 0.50 & 0.36 & 55.34 & 0.65 & 62.75 \\
\hline \multicolumn{6}{|c|}{$30 \mathrm{~min}$} \\
\hline 9 & 0.01 & 0.26 & 1.65 & 15.72 & 1.25 \\
\hline 16 & 0.02 & 0.25 & 3.31 & 7.56 & 2.50 \\
\hline 24 & 0.87 & 0.37 & 144.35 & 0.26 & 109.13 \\
\hline
\end{tabular}

Table 3. Current efficiency for silver cathode using $1.0 \% \mathrm{NaCl}$.

\begin{tabular}{|c|c|c|c|c|c|}
\hline Voltage (V) & Current (A) & $\begin{array}{l}\text { Total Chlorine } \\
(\mathrm{mg} / \mathrm{L})\end{array}$ & $\begin{array}{l}\text { Theoretical Total } \\
\text { Chlorine }(\mathrm{mg} / \mathrm{L})\end{array}$ & $\begin{array}{c}\text { Current } \\
\text { efficiency }(\%)\end{array}$ & $\begin{array}{l}\text { Current density, } \rho \\
\qquad\left(\mathrm{A} / \mathrm{m}^{2}\right)\end{array}$ \\
\hline \multicolumn{6}{|c|}{$10 \mathrm{~min}$} \\
\hline 9 & 0.01 & $<0.05$ & 0.55 & $<9.07$ & 1.25 \\
\hline 16 & 0.02 & 0.11 & 1.10 & 9.98 & 2.50 \\
\hline 24 & 0.46 & 0.09 & 25.35 & 0.35 & 57.50 \\
\hline \multicolumn{6}{|c|}{$20 \mathrm{~min}$} \\
\hline 9 & 0.09 & 0.07 & 9.92 & 0.71 & 11.25 \\
\hline 16 & 0.02 & 0.06 & 2.09 & 2.86 & 2.38 \\
\hline 24 & 0.93 & 0.10 & 102.52 & 0.10 & 116.25 \\
\hline \multicolumn{6}{|c|}{$30 \mathrm{~min}$} \\
\hline 9 & 0.01 & $<0.05$ & 1.65 & $<3.02$ & 1.25 \\
\hline 16 & 0.03 & $<0.05$ & 4.96 & $<1.01$ & 3.75 \\
\hline 24 & 0.95 & 0.17 & 157.08 & 0.11 & 118.75 \\
\hline
\end{tabular}

process. The production of active chlorine was in the order of $\mathrm{Ti} / \mathrm{IrO}_{2}>\mathrm{Ti} / \mathrm{RuO} 2>\mathrm{Ti} / \mathrm{Pt}-\mathrm{IrO} 2>\mathrm{BDD}>\mathrm{Pt}$ with $\mathrm{Ti} /$ $\mathrm{IrO}_{2}$ with the highest current density and platinum with the lowest current density. This result can be used as a reference in selecting suitable electrode for cathode and anode in this work.

Exchange current density, $\mathrm{i}_{0}$ does not depend on the electrical conductivity, $\sigma$ properties. Even though silver has higher electrical conductivity $\left(6.30 \times 10^{7} \mathrm{~S} / \mathrm{m}\right)$ compared to platinum $\left(9.43 \times 10^{6} \mathrm{~S} / \mathrm{m}\right), \mathrm{i}_{0}$ for platinum is higher than silver $\left(10^{-2} \mathrm{~A} / \mathrm{cm}^{2}\right.$ and $10^{-7} \mathrm{~A} / \mathrm{cm}^{2}$ respectively). Due to iron mixed with carbon is the main component of stainless steel. Thus, we assume that the $i_{0}$ for stainless steel followed the $i_{0}$ for Iron, $\mathrm{Fe}$ (approximately $10^{-6} \mathrm{~A} / \mathrm{cm}^{2}$ ), hence we can state that it is higher than silver $\left(10^{-7} \mathrm{~A} / \mathrm{cm}^{2}\right.$ respectively). Thus, this might be the reasons for the result obtained where titanium-stainless steel pair can produce more chlorine compared titanium-silver pairing (Table 1). Using stainless steel electrode, the ORP for AcEW is higher compared to silver cathode (647 and $486 \mathrm{mV}$ respectively). It is the same for AlEW and NEW (Table 1). Using different types of electrode does not have any significant effect on the $\mathrm{pH}$, dissolved oxygen (DO) and temperature of EW.

\subsection{Effect of electrical potentials on the physico- chemical properties of electroyzed water}

As the electrical potentials are increased, the current flow also increased (Table 2 and Table 3). Thus, electron change will also increase. Hsu, Lu, Hsu (2017) stated that electric potential is the main driving force of the electrolysis system. The higher the cell potential, the greater the amount of electric current that passes through the system and the higher the current density will be. Effects of chlorine production using different process conditions (electrode type, electrode size, electrical potential and stirring effect) on the production of electrolyzed deep ocean water were studied by Hsu, Hsia, Hsu (2015b). Results show that rising electrical potential from $6 \mathrm{~V}$ to $10 \mathrm{~V}$, significantly increased the chlorine production, electric current, current density, but significantly reduced the electrical and current efficiency $(p<0.05)$.

In this work, current density and current efficiency were calculated using Equation 1 and 2 respectively. In this work, titanium electrode was used as anode permanently for electrolysis process. Table 2 and 3 shows the experimental result using stainless steel and silver as cathode electrode respectively. As the electrical potentials were increased, the current flow in the electrolysis system increased and eventually increased the chlorine production. The current density increased but the current efficiency reduced. Increasing electrical potential does not have any significant effect on the dissolved oxygen (DO) and temperature of EW (Table 1) 
Table 4. Stainless steel, $1.0 \% \mathrm{NaCl}, 24 \mathrm{~V}$

\begin{tabular}{|c|c|c|c|c|c|c|c|c|c|c|c|c|c|c|c|}
\hline \multirow{2}{*}{$\begin{array}{l}\text { Time } \\
(\mathrm{min})\end{array}$} & \multicolumn{3}{|c|}{$\mathrm{pH}$} & \multicolumn{3}{|c|}{ ORP (mV) } & \multicolumn{3}{|c|}{$\begin{array}{c}\text { Free Chlorine } \\
(\mathrm{mg} / \mathrm{L})\end{array}$} & \multicolumn{3}{|c|}{$\begin{array}{l}\text { Total chlorine } \\
(\mathrm{mg} / \mathrm{L})\end{array}$} & \multicolumn{3}{|c|}{$\mathrm{DO}(\mathrm{mg} / \mathrm{L})$} \\
\hline & Bef. & Aft. & Diff. & Bef. & Aft. & Diff. & Bef. & Aft. & Diff. & Bef. & Aft. & Diff. & Bef. & Aft. & Diff. \\
\hline \multicolumn{16}{|c|}{ AcEW } \\
\hline 10 & 4.02 & 4.37 & -0.35 & 389 & 347 & 42 & 0.23 & 0.31 & -0.08 & 0.25 & 0.38 & -0.13 & 5.7 & 5.5 & 0.2 \\
\hline 20 & 3.04 & 3.46 & -0.42 & 407 & 384 & 23 & 0.34 & 0.32 & 0.02 & 0.36 & 0.43 & -0.07 & 5.5 & 5.1 & 0.4 \\
\hline 30 & 3.20 & 3.45 & -0.25 & 607 & 425 & 182 & 0.27 & 0.38 & -0.11 & 0.37 & 0.54 & -0.17 & 5.8 & 5.5 & 0.3 \\
\hline \multicolumn{16}{|c|}{ AlEW } \\
\hline 10 & 9.47 & 8.23 & 1.24 & 85 & 118 & 33 & 0.1 & 0.1 & 0 & 0.14 & 0.14 & 0 & 5.9 & 5.5 & 0.4 \\
\hline 20 & 10.23 & 10.08 & 0.15 & -711 & -180 & 531 & 0.19 & 0.18 & 0.01 & 0.23 & 0.21 & 0.02 & 5.7 & 5.2 & 0.5 \\
\hline 30 & 11.01 & 10.98 & 0.03 & -871 & -208 & 663 & 0.19 & 0.17 & 0.02 & 0.27 & 0.23 & 0.04 & 5.9 & 5.8 & 0.1 \\
\hline
\end{tabular}

(Comparison Run 1, 13 and 15). pH for AcEW generated at higher electrical potential of $24 \mathrm{~V}$ was lower compared to $16 \mathrm{~V}$ and $9 \mathrm{~V}$ (pH of 2.79, 4.00 and 3.80). Lower $\mathrm{pH}$ has better bactericidal effects (Huang et al., 2008). While the ORP of AcEW was higher when $24 \mathrm{~V}$ was used (Table 1).

\subsection{Effect of electrolysis time on the physico-chemical properties of electroyzed water}

In work by Hsu, Lu, Hsu (2017), electrolysis time did not have any significant effect on chlorine production when chlorine production reached maximum level. Hsu, Lu, Hsu (2017) used 180-420 mins electrolysis time. At low electric potential of $6.6 \mathrm{~V}$, current density slightly increased with time and at high electric potential of $10.0 \mathrm{~V}$, current density slightly decreased with time. Chlorine reached maximum $\left(10,498 \mathrm{mg} \mathrm{Cl}_{2} / \mathrm{L}\right)$ when electrolysis at $7.5 \mathrm{~V}$ and $342 \mathrm{mins}$ electrolysis time. Then, chlorine level started to decrease when electrolysis continued. Hsu, Lu, Hsu (2017) use 180-420 mins electrolysis time. Thus, we can conclude that as it reached maximum production of chlorine, the chlorine level will be reduced when the electrolysis time continued.

In this work, three electrolysis time was used $(10,20$ and 30 mins). Increasing electrolyzing time from 20 mins to 30 mins does not give any significant difference in chlorine production for both stainless steel and silver (Table 2 and 3). Moreover, using silver cathode, a similar pattern was observed at 10 mins electrolysis whereas the electrical potential was increased from $16 \mathrm{~V}$ to $24 \mathrm{~V}$ and the amount of chlorine produced decreased $(0.11 \mathrm{mg} / \mathrm{L}$ and $0.09 \mathrm{mg} / \mathrm{L}$ respectively). Increasing electrolysis time does not have any significant effect on the dissolved oxygen (DO) and temperature of EW (Table 2 and 3).

\subsection{Effect of $\mathrm{NaCl}$ concentration on the physico-chemical properties of electroyzed water}

In this work, three $\mathrm{NaCl}$ concentration was used $(0.1$, 0.5 and $1.0 \%$ ). Increasing the $\mathrm{NaCl}$ concentration did not give any significant effect on the $\mathrm{pH}$, ORP, free chlorine, total chlorine, DO and temperature of EW (AcEW, AlEW, and NEW) (Table 1). Thus using $0.5 \% \mathrm{NaCl}$ is sufficient to produce EW.

\subsection{Storage of electroyzed water}

Evaporation of chlorine over time and exposure to the atmosphere can reduce the effectiveness of AcEW and NEW (Rahman et al., 2016). Moreover, in the closed condition, chlorine can self-decomposed and ensure the $\mathrm{HOCl}$ breakdown which is one of the components in disinfection foodborne pathogens. The physical and chemical properties of electrolyzed water (AcEW, AlEW, and NEW) were measured after $24 \mathrm{hrs}$ where the bottles were stored in a dark brown tightly screw closed bottle at room temperature $\left(25-30^{\circ} \mathrm{C}\right)$. Aerobic bacteria and anaerobic bacteria can optimally grow at ORP range of +200 to $+800 \mathrm{mV}$ and -700 to $+200 \mathrm{mV}$, respectively. While low $\mathrm{pH}$ (2.3-2.7) of AcEW may sensitize the outer membrane of bacterial cells to allow Hypochlorous acid ( $\mathrm{HOCl})$ to enter into bacterial cells (McPherson, 1993). It is very important to maintain the ORP and $\mathrm{pH}$ of AcEW (ORP $>800 \mathrm{mV}, \mathrm{pH} 2.7$ ) and AlEW (Less than $-700 \mathrm{mV}$ ) to maintain the effectiveness of EW as sanitizer and cleaner. Using stainless steel cathode, at $1.0 \% \mathrm{NaCl}, 30$ mins electrolysis time, the ORP of AlEW reduced drastically from $-871 \mathrm{mV}$ to $-208 \mathrm{mV}$ after $24 \mathrm{hrs}$ of storage (Table 4). The $\mathrm{pH}$ reduced from 11.01 to 10.98 . At the same electrolysis parameters, $\mathrm{pH}$, ORP, free chlorine and total chlorine of AcEW changed drastically (Table 4). Weaker acidity, lower ORP, and less chlorine were detected after $24 \mathrm{hrs}$ of storage. Thus, we can assume that the effectiveness of EW has reduced after 24 hrs of storage. For EW generated using the lab-scale electrolyzing unit, it is suggested for immediate usage after production to minimize the properties change due to time and exposure to the atmosphere.

\section{Conclusion}

It is essential to use cleaning chemical for cleaning of food equipment surfaces. The need to find an alternative cleaning fluid has become more urgent as we have a strong concern for the health of the environment. 
EW has a potential as a good green cleaner and sanitiser. The best electrolyzing parameters can be found at $24 \mathrm{~V}$, $0.5 \% \mathrm{NaCl}, 20$ minutes electrolyzing time using titanium as anode and stainless steel as cathode. The optimal AlEW, AcEW, and NEW obtained from this study will be used for future study on the removal of bacterial contaminated fat-based fouling deposit. Three types of microbes associated with foodborne illness (Listeria monocytogenes, Escherichia coli O157: H7 and Salmonella enteritidis) will be studied.

\section{Acknowledgement}

The authors would like to acknowledge the financial support provided by Universiti Putra Malaysia (9548500) Putra IPS grant.

\section{References}

Dev, R.S.S., Demirci, A., Robert, E.G. and Puri, V.M. (2014). Optimization and modeling of an electrolyzed oxidizing water based Clean-In-Place technique for farm milking systems using a pilotscale milking system. Journal of Food Engineering, 135,1-10.

j.jfoodeng.2014.02.019

Fabrizio K.A. and Cutter, C.N. (2004). Comparison of electrolyzed oxidizing water with other antimicrobial interventions to reduce pathogens on fresh pork. Meat Science, 68(3), 463-468. https:// doi.org/10.1016/j.meatsci.2004.04.013

Huang Y.R., Hung, Y.C., Hsu, S.Y., Huang, Y.W. and Hwang, D.F. (2008). Application of electrolyzed water in the food industry. Food Control, 19(4), 329 -345. https://doi.org/10.1016/j.foodcont.2007.08.012

Hsu, S.Y. (2005). Effects of flow rate, temperature and salt concentration on chemical and physical properties of electrolyzed oxidizing water. Journal of Food Engineering, 66(2), 171-176. https:// doi.org/10.1016/j.jfoodeng.2004.03.003

Hsu, G.S.W., Hsia, C.W. and Hsu, S.Y. (2015a). Effects of electrode settings on chlorine generation efficiency of electrolyzing seawater. Journal of Food and Drug Analysis, 23(4), 729-734. https:// doi.org/10.1016/j.jfda.2015.06.007

Hsu, G.S.W., Hsia, C.W. and Hsu, S.Y. (2015b). Effects of process conditions on chlorine generation and storage stability of electrolyzed deep ocean water. Journal of Food and Drug Analysis, 23(4), 735-741. https://doi.org/10.1016/j.jfda.2015.05.002

Hsu, G.S.W. and Hsu, S.Y. (2016). Effects of electrode gap and electric potential on chlorine generation of electrolyzed deep ocean water. Journal of Food and Drug Analysis, 24(3), 575-578. https:// doi.org/10.1016/j.jfda.2016.01.006

Hsu, G.S.W., Lu, Y.F. and Hsu, S.Y. (2017). Effects of electrolysis time and electric potential on chlorine generation of electrolyzed deep ocean water. Journal of Food and Drug Analysis, 25(4), 759-765. https:// doi.org/10.1016/j.jfda.2016.07.001

Jeong, J., Kim, C. and Yoon, J. (2009). The effect of electrode material on the generation of oxidants and microbial inactivation in the electrochemical disinfection processes. Water Research, 43(4), 895901. https://doi.org/10.1016/j.watres.2008.11.033

Khalid, N.I., Nordin, N., Chia, Z.Y., Ab Aziz, N., Nuraini, A.A, Taip, F.S. and Ahmedov, A. (2016). A removal kinetics approach for evaluation of economic cleaning protocols for pink guava puree fouling deposit. Journal of Cleaner Production, 135, 1317-1326.

ttps://doi.org/10.1016/

j.jclepro.2016.06.095

Kim, C., Hung, Y.C. and Brackett A.E. (2000). Roles of oxidation-reduction potential in electrolyzed oxidizing and chemically modified water for the inactivation of food-related pathogens. Journal of Food Protection, 63(1), 19-24. https:// doi.org/10.4315/0362-028X-63.1.19

Liao, L.B., Chen, W.M. and Xiao, X.M. (2007). The generation and inactivation mechanism of oxidationreduction potential of electrolyzed oxidizing water. Journal of Food Engineering, 78(4), 1326-1332. https://doi.org/10.1016/j.jfoodeng.2006.01.004

Liu, C., Duan, J. and Su, Y.C. (2006). Effects of electrolyzed oxidizing water on reducing Listeria monocytogenes contamination on seafood processing surfaces. International Journal of Food Microbiology, 106(3), 248-253. https:// doi.org/10.1016/j.ijfoodmicro.2005.06.020

McPherson, L.L. (1993). Understanding ORP's in the disinfection process. Water Engineering and Management, 140, 29-31.

Natarajan. K.A. (2018). Lecture 9: Exchange Current Density - Polarization Relationships. Retrieved on 13 March 2018 from website: http://nptel.ac.in/ courses/113108051/module2/lecture9.pdf.

Park, H., Hung, Y.C. and Chung, D. (2004). Effects of chlorine and $\mathrm{pH}$ on efficacy of electrolyzed water for inactivating Escherichia coli $\mathrm{O} 157$ : $\mathrm{H} 7$ and Listeria monocytogenes. International Journal of Food Microbiology, 91(1), 13-18. https://doi.org/10.1016/ S0168-1605(03)00334-9

Rahman, S.M.E., Khan, I. and Oh, D.H. (2016). Electrolyzed water as a novel sanitizer in the food industry: Current Trends and Future Perspectives. Comprehensive Reviews in Food Science and Food 
Safety, 15(3), 471-490. https://doi.org/10.1111/15414337.12200

Venkitanarayanan, K.S., Ezeike, G.O., Hung, Y.C. and Doyle, A.P. (1999). Efficacy of electrolyzed oxidizing water for inactivating Escherichia coli O157: H7, Salmonella enteritidis, and Listeria monocytogenes. Applied and Environmental Microbiology, 65(9), 4276-4279.

Walker S.P., Demirci, A., Graves, R.E., Stephen, B.S. and Roberts, R.F. (2005). Response surface modelling for cleaning and disinfecting materials used in milking systems with electrolysed oxidizing water. International Journal of Dairy Technology, 58(2), 65-73. https://doi.org/10.1111/j.14710307.2005.00190.x

Wang, X., Puri, V.M., Demirci, A. and Graves, R.E. (2016). Mathematical modeling and cycle time reduction of deposit removal from stainless steel pipeline during cleaning-in-place of milking system with electrolyzed oxidizing water. Journal of Food Engineering, 170, 144-159. ttps://doi.org/10.1016/ j.jfoodeng.2015.09.027 